\title{
Purification and properties of a major, low molecular weight protein released by the trophoblast of sheep blastocysts at Day 13-21
}

\author{
J. D. Godkin, F. W. Bazer*, J. Moffatt*, F. Sessions and R. M. Roberts \\ Department of Biochemistry and Molecular Biology and, ${ }^{*}$ Department of Animal Science, \\ University of Florida, Gainesville, Florida 32610, U.S.A.
}

\begin{abstract}
Summary. Sheep blastocysts (Day 13-21) incubated in a modified Minimum Essential Medium released proteins into the medium at an approximately linear rate over a $24-\mathrm{h}$ period. Single Day-16 blastocysts converted $2-8 \%$ of the radioactivity supplied (100 $\mu \mathrm{Ci} \mathrm{L-}\left[{ }^{3} \mathrm{H}\right]$ leucine) into non-dialysable macromolecules which were released into the medium. Two-dimensional polyacrylamide gel electrophoresis revealed that at Day 13 there was only one major product (Protein X), consisting of three closely similar isoelectric species (pI of denatured polypeptides about 5.5), each with molecular weights of 17000 . Between Days 14 and 21 additional proteins were detected. One of these was of high molecular weight $(>660000)$ and did not appear on the two-dimensional gels, but Protein $\mathrm{X}$ continued to predominate until Day 23 when it could not be detected. Explants of chorion from Day 30 of pregnancy failed to secrete Protein X. Protein X was released in significant quantities (50-100 $\mu \mathrm{g}$ per $24 \mathrm{~h}$ ) by the trophoblast but not the yolk sac of Day-14 and Day-16 conceptuses, but was present in very low amounts in the tissues. Protein $\mathrm{X}$ from the incubation medium of Day-14 and Day-16 conceptuses was purified by successive DEAE ion exchange and Sephacryl S-200 gel chromatography. Because Protein X and some of the other proteins are produced transiently between Days 13 and 21, it is possible that they may play a role in maternal recognition of pregnancy in sheep.
\end{abstract}

\section{Introduction}

One of the most intriguing aspects of reproduction is the interaction between the developing conceptus and maternal tissues which results in the adjustment of endocrinological and immunological processes necessary for a successful pregnancy. "Early pregnancy factors", presumably originating from the conceptus, have been reported in the serum of pregnant mice (Morton, Hegh \& Clunie, 1974, 1976), women (Morton, Rolf, Clunie, Anderson \& Morrison, 1977) and sheep (Morton, Nancarrow, Scaramuzzi, Evison \& Clunie, 1979) shortly after fertilization. In sheep, Moor \& Rowson (1966a, b) demonstrated by embryo transfer experiments that a conceptus must be in the gravid uterine horn by Day 13 (oestrus = Day 0 ) in order for pregnancy to be maintained. Daily injection of Day-14-15 conceptus homogenates into the uterine lumen of cyclic ewes prolonged the oestrous cycle while Day- 25 conceptus homogenates or heat-treated, whole Day-12-14 blastocysts had no effect (Rowson \& Moor, 1967). In similar experiments Martal, Lacroix, Loudes, Saunier \& Wintenberger-Torrès (1979) found that while the intrauterine injection of Day-14-16 conceptus homogenates and extracts prolonged the lifespan of the corpus luteum (CL), Day-21-23 material did not in general do so. 
Again, the anti-luteolytic activity of Day-14-16 blastocysts appeared to be heat labile and inactivated by proteases. These data suggest that proteinaceous products from the conceptus play a role in the events leading to establishment of pregnancy and that the appearance or action of these products occurs during a short but critical time during early pregnancy.

In the present study our objective was to identify the proteins synthesized by the conceptus between Days 13 and 23 of pregnancy and to purify those produced in major amounts. Our approach, like that of others (Fishel \& Surani, 1980), has been to culture rather than to extract blastocysts and then to analyse the proteins released into the incubation medium. The rationale behind these experiments was that if blastocyst proteins mediate fetal-maternal interactions during this phase of pregnancy, then these are likely to be among the major products released by the conceptus.

\section{Materials and Methods}

Materials. Tissue culture supplies were purchased from Grand Island Biological Co., Grand Island, New York; acrylamide, $N, N, N^{\prime}, N^{\prime}$-tetramethylenediamine and X-Omat RP film XRP-1 were products of Eastman-Kodak, Rochester, New York; L- $\left[4,5-{ }^{3} \mathrm{H} \mid\right.$ leucine (sp.act. 62 $\mathrm{Ci} / \mathrm{mmol}$ ) and $\mathrm{D}-\left[6{ }^{3} \mathrm{H}\right]$ glucosamine hydrochloride (sp.act. $4 \cdot 1 \mathrm{Ci} / \mathrm{mmol}$ ) were obtained from the Radiochemical Centre, Amersham, U.K.; Coomassie blue R-250 and $N, N^{\prime}-$ diallyltartardiamide were from Bio-Rad Laboratories, Richmond, California; SDS (specifically pure) was from BDH Chemicals Ltd, Poole, U.K.; diethylaminoethyl cellulose was purchased from Whatman, Clifton, New Jersey; ampholines were from LKB, Uppsala, Sweden; amino acids, dithiothreitol, protein standards, 2-mercaptoethanol, agarose, and pregnant mare serum gonadotrophin (PMSG) were from Sigma Chemical Co., St. Louis, Missouri; urea was from Pierce Chemicals, Rockford, Illinois; Sephacryl S-200 was a product of Pharmacia Fine Chemicals, Piscataway, New Jersey. All inorganic chemicals used were reagent grade or better.

Animals. Adult crossbred ewes, primarily of Rambouillet breeding, were checked twice daily for oestrus with vasectomized rams. Ewes selected as embryo donors were mated to two intact rams at oestrus. Some animals were induced to superovulate by intramuscular injection of 750 i.u. PMSG on Day 12 of the oestrous cycle (oestrus = Day 0 ) and mated at the subsequent oestrus. Pregnant ewes were anaesthestized (methoxyflurane) and the reproductive tract was exposed via midventral laparotomy, Blastocysts were flushed from uteri on Days 13 through 21 of pregnancy with sterile medium (MEM, see below) at $37^{\circ} \mathrm{C}$ and collected in sterile serum bottles by a procedure similar to that described by Moor \& Rowson (1964). Alternatively, ewes were hysterectomized and conceptuses were dissected out of the uterus under a sterile, laminar-flow hood.

Medium preparation. Eagle's minimum essential medium (MEM) was prepared according to the method of Basha, Bazer \& Roberts (1979) except that the L-leucine content was limited to $5.2 \mu \mathrm{g} / \mathrm{ml}(1 / 10$ normal amount $)$ to enhance the incorporation of the $\mathrm{L}-\left[4,5-{ }^{3} \mathrm{H}\right]$ leucine which was added to the cultures. Phenol red $(10 \mu \mathrm{g} / \mathrm{ml})$ was also added as an indicator. MEM was supplemented with penicillin $(200 \mathrm{units} / \mathrm{ml})$, streptomycin $(200 \mu \mathrm{g} / \mathrm{ml})$ and fungizone $(0.5$ $\mu \mathrm{g} / \mathrm{ml}), 0.2$ units insulin $/ \mathrm{ml}$ and $1 \%(\mathrm{v} / \mathrm{v})$ non-essential amino acids. The medium was filter-sterilized and stored at $4^{\circ} \mathrm{C}$ until used.

In-vitro culture of conceptuses. Conceptuses were removed from the uterus under sterile conditions and transferred to sterile Petri dishes containing $15 \mathrm{ml} \mathrm{MEM} ; 100 \mu \mathrm{Ci} \mathrm{L}-\left[{ }^{3} \mathrm{H}\right]$ leucine or $100 \mu \mathrm{Ci} \mathrm{D}-\left[6-{ }^{3} \mathrm{H} \mid\right.$ glucosamine were added. Each dish was then transferred to a controlled atmosphere chamber (Bellco Biological Glassware, Vineland, New Jersey). The chamber was flushed for $1 \mathrm{~min}$ with $50 \% \mathrm{O}_{2}-45 \% \mathrm{~N}_{2}-5 \% \mathrm{CO}_{2}$ (by volume) and incubated at $37^{\circ} \mathrm{C}$ in the dark on a rocking platform (6 cycles/min) according to the method of Basha et al. (1980). This ensured that the cultures were alternately immersed in medium and then exposed directly to the gaseous atmosphere. The technique was originally described by Barrett, McDowell, Frank, 
Harris \& Trump (1976) and is used widely for culture of tissue and organ explants from a variety of sources (see Trump, Resau \& Barrett, 1980) and has been employed to maintain viability of uterine endometrial explants from pigs for up to 50 days (J. D. Godkin \& R. M. Roberts, unpublished observation). After 24-48 $\mathrm{h}$ incubations were terminated by chilling the incubation mixture on ice and then centrifuging at $12000 \mathrm{~g}$ for $20 \mathrm{~min}$ to separate tissue and medium. The medium was extensively dialysed (molecular weight cut off $\simeq 3500$ ) against 10 mM-Tris- $\mathrm{HCl}$ buffer $(\mathrm{pH} \mathrm{8.2)}$ to remove low molecular weight compounds, e.g. salts and unincorporated radiolabelled precursors.

In order to separate the yolk sac from the trophoblast, the whole blastocyst was gently teased open to expose the yolk sac which was then gently held by means of forceps and dissected away from attached trophoblast tissue. Incubations of dissected tissues were then carried out as above.

Synthesis and release of protein. Proteins synthesized and released into the incubation medium were monitored by observing the incorporation of radiolabelled amino acids into macromolecules over a 30 -h incubation period. Aliquots $(0.4 \mathrm{ml})$ of medium were removed at regular intervals, dialysed extensively against $10 \mathrm{mM}$-Tris- $\mathrm{HCl}(\mathrm{pH} 8.2)$ and radioactive content measured to determine the time course of appearance of non-diffusible material (presumably proteins and complex saccharides).

Preparation of samples for electrophoresis. Dialysed medium $(3 \mathrm{ml})$ was freeze-dried and the dried material dissolved in $1 \mathrm{ml} 5 \mathrm{~mm}-\mathrm{K}_{2} \mathrm{CO}_{3}$ containing $9.4 \mathrm{M}$-urea, 2\% (v/v) Nonidet P-40 and $0.5 \%(\mathrm{w} / \mathrm{v})$ dithiothreitol and used for two-dimensional polyacrylamide gel electrophoresis (PAGE). Conceptus tissue was suspended in $0.5 \mathrm{ml} 5 \mathrm{~mm}-\mathrm{K}_{2} \mathrm{CO}_{3}$ and $9.3 \mathrm{M}$-urea and sonicated $(4 \times 15 \mathrm{sec}$ at 1 -min intervals) in an ice bath using a Bronwill Biosonic at $20-30 \%$ probe intensity. The sonicated material was made to $2 \%(\mathrm{v} / \mathrm{v})$ with Nonidet P-40 and $0.5 \%(\mathrm{w} / \mathrm{v})$ with dithiothreitol and centrifuged at $20000 \mathrm{~g}$ for $30 \mathrm{~min}$ at $18^{\circ} \mathrm{C}$. The clear supernatant was used for electrophoretic analysis of polypeptides.

Two-dimensional polyacrylamide gel electrophoresis. This analysis was performed according to a modification of the method of O'Farrell (1975) described by Horst \& Roberts (1979), and as employed by Basha et al. (1980) for analysis of proteins released into the medium by explant cultures of porcine endometrium. After electrophoresis, slab gels were impregnated with sodium salicylate (1 M; $30 \mathrm{~min}$ ) (Chamberlain, 1979) and dried; fluorographs were prepared (Laskey \& Mills, 1975) from Kodak XRP-1 X-ray film.

Protein fractionation by ion-exchange and gel filtration chromatography. Non-diffusible material retained after dialysis of incubation medium was adsorbed onto a diethylaminoethyl cellulose (DEAE) column $(1.5 \times 10 \mathrm{~cm})$ equilibrated with $10 \mathrm{mM}$-Tris- $\mathrm{HCl}(\mathrm{pH} 8.2)$ and, after washing the column thoroughly, the bound protein was eluted with $300 \mathrm{ml}$ of a linear salt gradient $(0-0.5 \mathrm{M}-\mathrm{NaCl})$ and $3 \mathrm{ml}$ fractions were collected. The radioactive content of each fraction was determined and protein peaks were pooled and dialysed extensively against 10 mM-Tris- $\mathrm{HCl}$ buffer $(\mathrm{pH} 8 \cdot 2)$. Aliquots of dialysed protein peaks from ion-exchange chromatography were freeze-dried and submitted to two-dimensional or single-dimension (Laemmli, 1970) polyacrylamide gel electrophoresis, enabling visual identification of the polypeptides composing each peak. Dialysed proteins of peaks were also concentrated by exchanging the material onto a short $(1 \times 0.5 \mathrm{~cm})$ DEAE cellulose column and eluting the bound material with $3-5 \mathrm{ml} 0.5 \mathrm{M}-\mathrm{NaCl}$. Concentrated samples were then submitted to gel filtration chromatography on a Sephacryl S-200 column $(90 \times 1.5 \mathrm{~cm})$ or Sepharose CL-6B column $(90 \times 1.5 \mathrm{~cm})$ equilibrated in $10 \mathrm{~mm}-\mathrm{Tris}-\mathrm{HCl}, 0.3 \mathrm{M}-\mathrm{NaCl}(\mathrm{pH} 8.2)$. Protein standards used with the former were blue dextran, bovine serum albumin, ovalbumin, chymotrypsinogen and ribonuclease A. Blue dextran, thyroglobulin and bovine serum albumin were employed with the latter.

Protein determination. Protein concentrations were determined by the method of Lowry, Rosebrough, Farr \& Randall (1951), using bovine serum albumin as the standard. 


\section{Results}

\section{Release of radioactivity into the medium}

Sheep blastocysts were incubated in medium in the presence of $\mathrm{L}-\left[{ }^{3} \mathrm{H} /\right.$ leucine to follow the release of protein synthesized by tissues during incubation. At all stages of pregnancy tested considerable amounts of macromolecular material (presumably proteins) were released into the medium. However, a detailed time course, employing several conceptuses has only been carried out with Day-16 material (Text-fig. 1). Release was approximately linear between 4 and $30 \mathrm{~h}$. A slight lag was evident during the initial $4 \mathrm{~h}$ but there was no evidence for a decrease in the synthetic activity towards the end of the experiment which might have indicated that the tissue was losing viability. Approximately $2-8 \%$ of the ${ }^{3} \mathrm{H}$ supplied was recovered in polypeptides released into the medium. The large variation in protein synthetic activity between conceptuses which is evident in Text-fig. 1 did not appear to be due to differences in conceptus size, because when results were expressed on a weight basis just as much variability was evident. Essentially similar results were obtained with $\mathrm{D}-\left[6-{ }^{3} \mathrm{H}\right]$ glucosamine as with $\mathrm{L}$-leucine, namely a $4 \mathrm{~h}$ lag followed by a linear rate of release over the next $26 \mathrm{~h}$ (results not shown).

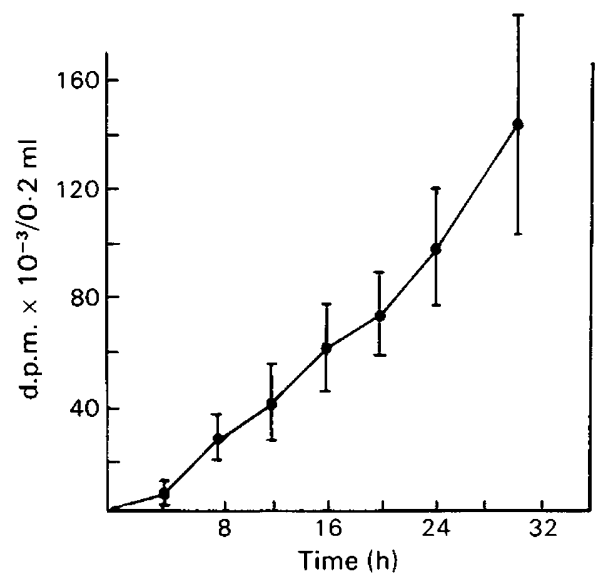

Text-fig. 1. Release of ${ }^{3} \mathrm{H}$-labelled, macromolecular components by Day-16 conceptuses over a 30-h period. Single conceptuses were incubated in $15 \mathrm{ml}$ medium containing $100 \mu \mathrm{Ci}$ $\mathrm{L}-\left[{ }^{3} \mathrm{H}\right]$ leucine. Samples of medium $(0.4 \mathrm{ml})$ were withdrawn at $4 \mathrm{~h}$ intervals, dialysed against $0.01 \mathrm{M}$-Tris- $\mathrm{HCl}(\mathrm{pH} \mathrm{8.2)}$ as described in 'Methods' and their radioactive contents measured. Results are mean $\underline{ \pm}$ s.e.m. for 6 experiments.

\section{Polypeptides in the incubation medium}

Two-dimensional PAGE. Analysis of polypeptides present in the incubation medium and in tissue from conceptuses surgically removed from ewes on Days 13 through 23 were carried out by two-dimensional PAGE, followed by fluorography of the dried gels (Plate 1). During the initial stages of blastocyst elongation (Day 13) the major polypeptides synthesized and released into the incubation medium constituted a group of low molecular weight acidic proteins (Protein $\mathrm{X}$ ). As seen in Pl. 1, Fig. 1, the proteins had an apparent molecular weight of about 17000 as determined by their electrophoretic mobilities in presence of SDS. The isoelectric points (pI) under denaturing conditions in the presence of urea were between 5.4 and 5.7. The proteins consisted of three major isoelectric species which seemed to vary in their relative proportions from experiment to experiment.

As the conceptus continued to develop (Pl. 1, Fig. 2, Day 14), the pattern of proteins released into the medium became more complex. By Day 21 protein synthesis was still active 
and although changes in the array of proteins secreted did occur between Days 13 and 21 , the low molecular weight acidic protein remained the major component throughout this period. However, by Day 23, this component could no longer be detected (Pl. 1, Fig. 4).

When gels from Day-14 conceptus medium were stained by Coomassie blue a large number of polypeptides were detected (Pl. 2, Fig. 5), the majority of which were radioactive (Pl. 2, Fig. 6). However, there was poor correlation between the radioactive content of the various spots and their staining intensities. The low molecular weight acidic components, for example, which constitute the predominant radioactive spots, stained only poorly with Coomassie blue.

Sections of chorion from Day-30 conceptuses did not release detectable amounts of radioactive Protein $X$ into the medium: when equivalent volumes of medium from Day-30 chorionic tissue, which had been labelled by a procedure identical to that in Plate 1, were analysed, the fluorographs were blank. As at Day 23, the low molecular weight acidic protein was clearly not present.

Analysis of tissue proteins synthesized during the incubation period by two-dimensional PAGE, showed that the pattern of labelled polypeptides was quite different from that in the medium (PI. 2, Fig. 7). The major tissue protein synthesized had a molecular weight of about 45000 and corresponded in mobility with actin. Very little of the low molecular weight, Protein $\mathrm{X}$ was detected in the tissue extracts. When labelled chorionic tissue from Day-30 conceptuses was analysed in a similar manner, many polypeptides were found to be radioactive. This suggests that the Day-30 chorionic tissue, although not active in secretion, was capable of synthesizing protein.

Ion-exchange chromatography. Data derived from ion-exchange chromatography on columns of DEAE-cellulose were consistent with those obtained by two-dimensional PAGE (Text-fig. 2); i.e. blastocysts in the initial stages of elongation synthesized only one major class of protein, evident as a peak of radioactivity eluting late in the salt gradient. As development of the blastocysts continued, the pattern of protein synthesis became more complex. The additional peaks of radioactivity are presumed to contain the many other polypeptides noted on the two-dimensional gels. For example, when the most acidic, late eluting, peak collected between 160 and $190 \mathrm{ml}$ was concentrated and analysed by one-dimensional polyacrylamide gel electrophoresis, one major band of radioactivity was detected on the gel (Text-fig. 3, lane 3). By contrast, fractions between 100 and $150 \mathrm{ml}$ contained a variety of labelled polypeptides (Text-fig. 3, lane 2). The first peak to elute from the column was apparently of very high molecular weight; after electrophoresis the radioactivity was recovered in the stacking gel or at the very top of the running gel (Text-fig. 3, lane 1). Attempts to analyse this material by two-dimensional PAGE have been unsuccessful because it fails to enter the first dimension isoelectric focussing gel. Polypeptides in DEAE peak $1(60-90 \mathrm{ml})$ do not, therefore, appear on the gels shown in Plate 1.

\section{Gel filtration of peak 1 material}

From Day 14 onwards considerable amounts of radioactivity were found in peak 1 (60-90 $\mathrm{ml}$ ) from the DEAE-ion-exchange column. When this material was concentrated and subjected to gel filtration it eluted at the void volume of the Sephacryl S-200 column and ahead of thyroglobulin on the Sepharose CL-6B column (results not shown). Its molecular weight was, therefore, greater than 660000 . These results are consistent with the behaviour of the protein during SDS-polyacrylamide gel electrophoresis (Text-fig. 3, lane 1).

\section{Purification of the low molecular weight components}

Following ion-exchange chromatography, the low molecular weight acidic component (which eluted as the last peak between 160 and $190 \mathrm{ml}$ ) was concentrated and submitted to gel 


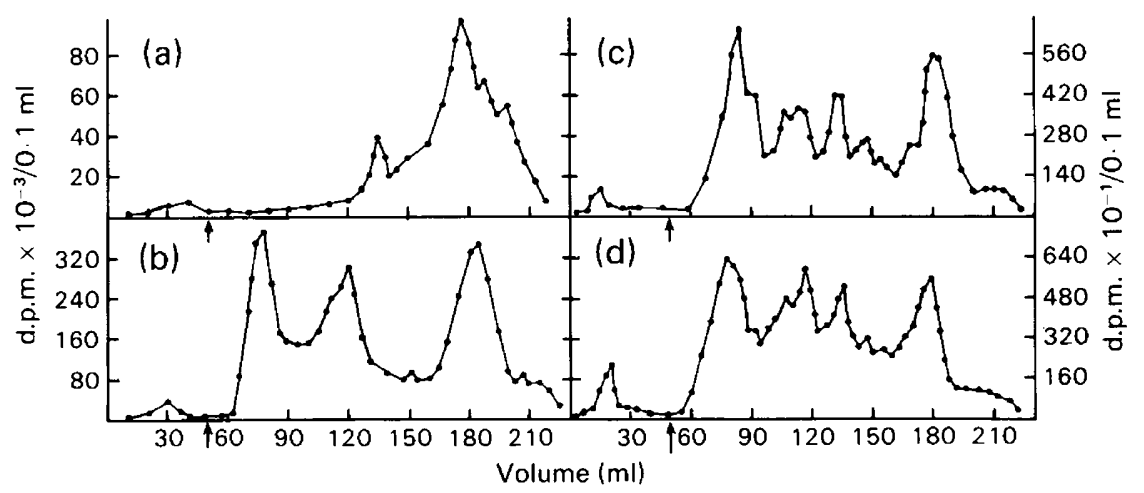

Text-fig. 2. DEAE-ion-exchange chromatography of dialysed medium following a 24-h incubation of sheep conceptuses in $\mathrm{L}-\left({ }^{3} \mathrm{H} /\right.$ leucine $(100 \mu \mathrm{Ci})$. Values are for single incubations of conceptuses at (a) Day 13, (b) Day 14, (c) Day 18 and (d) Day 21. Arrow indicates start of the $\mathrm{NaCl}$ gradient. The column was washed immediately after loading, with $0.01 \mathrm{M}-\mathrm{Tris}-\mathrm{HCl}(\mathrm{pH}$ $8.2)$ and then eluted with a $300 \mathrm{ml}(0-0.5 \mathrm{M}-\mathrm{NaCl}$ in $0.01 \mathrm{M}$-Tris- $\mathrm{HCl})$ salt gradient. Only the initial $180 \mathrm{ml}$ of the gradient (i.e. $0-0.3 \mathrm{M}-\mathrm{NaCl}$ ) is shown because this contained all of the radioactivity. Note the differences in radioactivity scale between the different days.

\section{PLATE 1}

Fluorographs of dried, two-dimensional polyacrylamide gels used for analysis of the dialysed medium following incubation of conceptuses in $\mathrm{L}-\left[{ }^{3} \mathrm{H}\right]$ leucine $(100 \mu \mathrm{Ci})$. In each case one-fifth $(3$ $\mathrm{ml}$ ) of the total, dialysed medium was freeze-dried, dissolved in $0.5 \mathrm{ml}$ alkaline urea buffer and $200 \mu \mathrm{l}$ were loaded onto the first dimension gel. Exposure of the fluorographs was 1 week.

Fig. 1. Medium from a Day-13 conceptus.

Fig. 2. Medium from a Day-14 conceptus.

Fig. 3. Medium from a Day-21 conceptus.

Fig. 4. Medium from a Day-23 conceptus.

\section{PLATE 2}

Figs 5 and 6. Two-dimensional polyacrylamide gel electrophoresis of Day-14 conceptus incubation medium.

Fig. 5. Gel stained by Coomassie blue with about $200 \mu \mathrm{g}$ of protein loaded.

Fig. 6. Fluorograph of the gel shown in Fig. 5.

Fig. 7. A fluorograph of a two-dimensional polyacrylamide gel in which solubilized whole tissue from a Day-14 conceptus was analysed. The major radioactive spot in the middle of the gel is actin. Note the absence of the low molecular weight acidic polypeptides (Protein $\mathrm{X}$ ) from the medium.

\section{PLATE 3}

Figs 8 and 9. Two-dimensional polyacrylamide gel electrophoresis of purified Protein X (right hand sides of gels only).

Fig. 8. Gel stained by Coomassie blue.

Fig. 9. Fluorograph of the gel in Fig. 8.

Figs 10 and 11. Fluorographs of two-dimensional polyacrylamide gels comparing the secretory products of the yolk sac (Fig. 10) and trophoblast (Fig. 11). Tissues were separated from a single Day-14 conceptus and incubated separately in $100 \mu \mathrm{Ci} \mathrm{L}-\left[{ }^{3} \mathrm{H}\right] l$ eucine for $24 \mathrm{~h}$. Sample preparation was identical to that described in Plate 1. 
PLATE 1

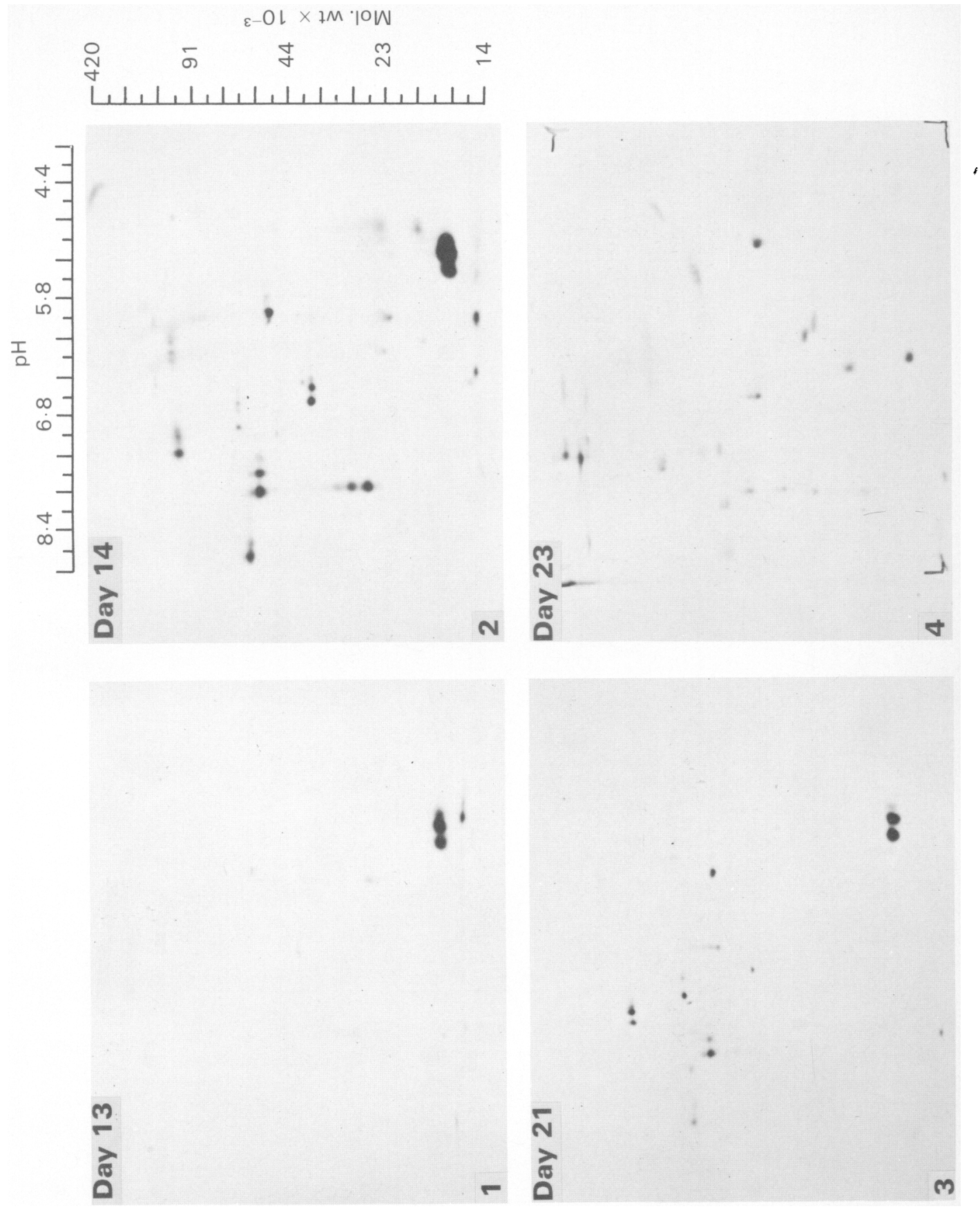

(Facing p. 146) 
PLATE 2
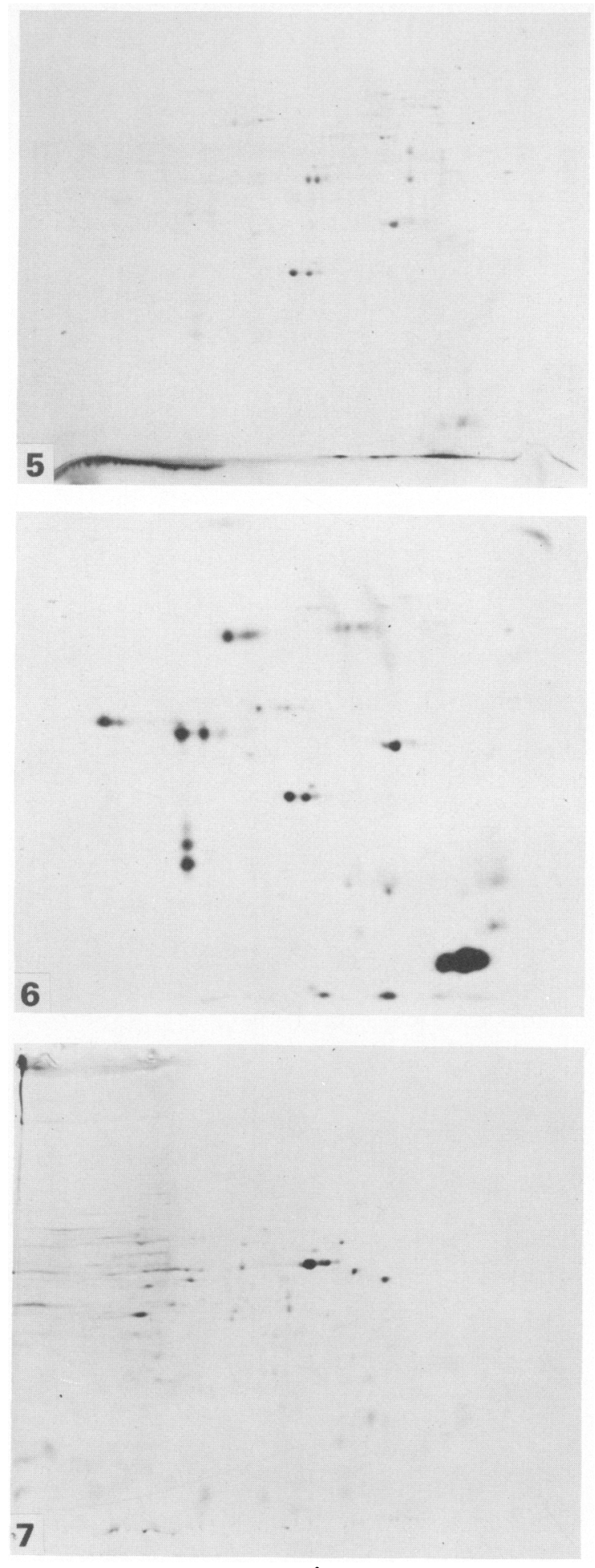
PLATE 3

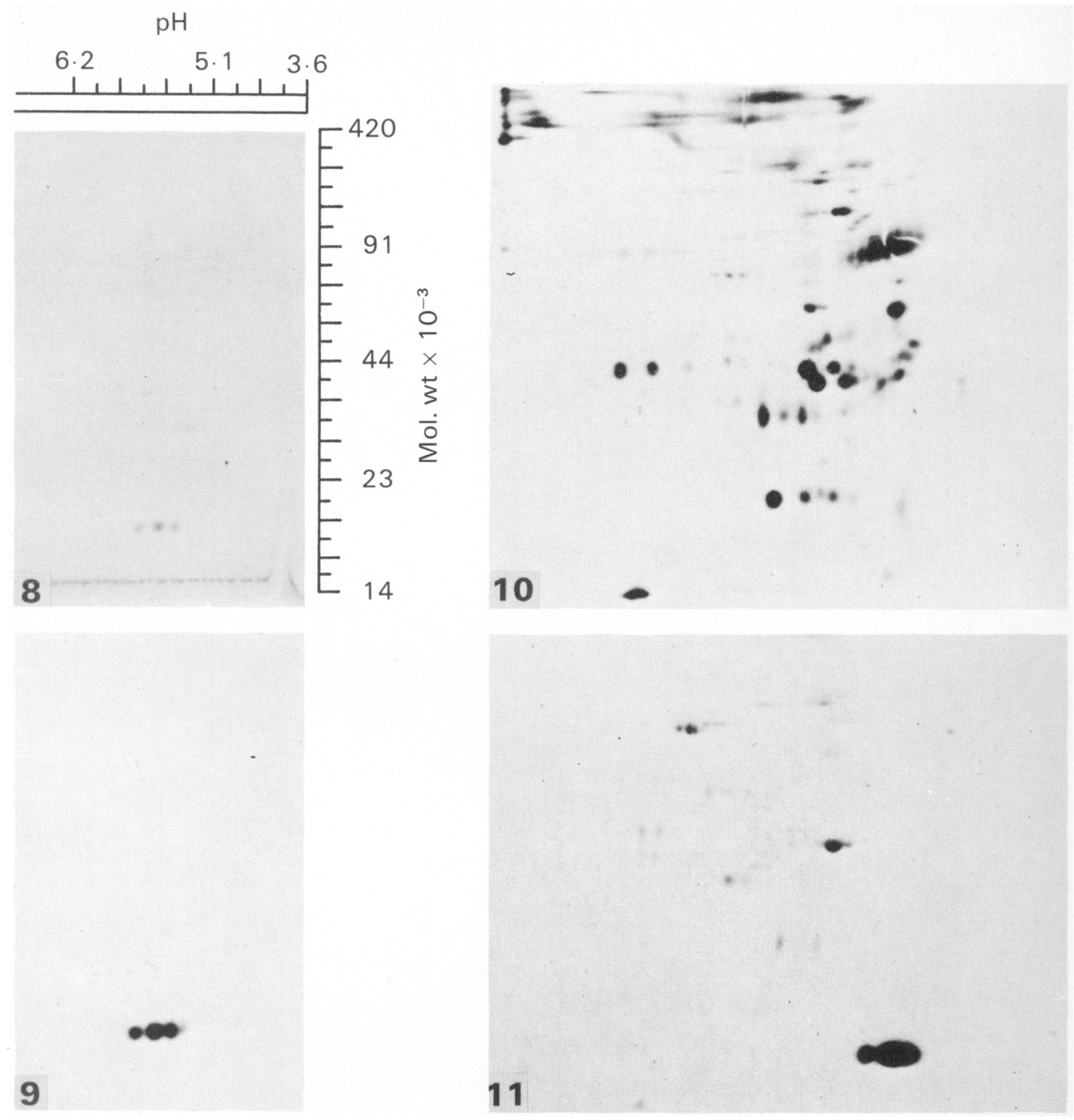




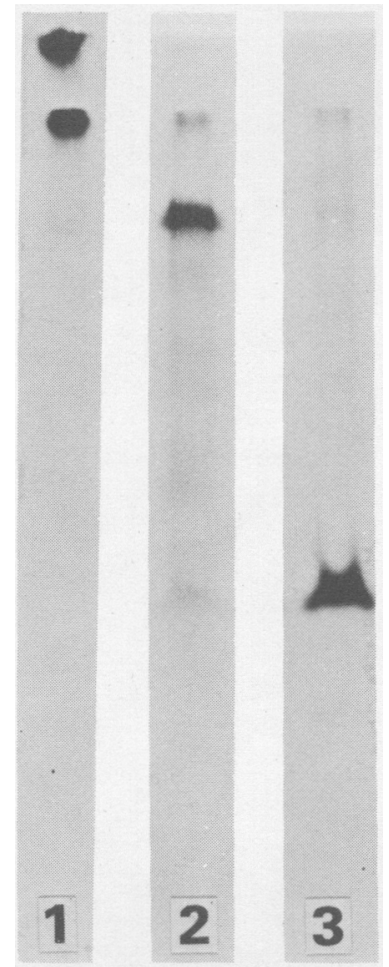

Text-fig. 3. One dimensional, SDS-polyacrylamide gel electrophoresis of polypeptide components fractionated by DEAE-cellulose ion exchange chromatography of incubation medium from a Day 14 conceptus (Text-fig. 2b). Lane 1 contains material from the peak eluting between 60 and $90 \mathrm{ml}$; Lane 2, material eluting between 100 and $150 \mathrm{ml}$; Lane 3, material eluting between 160 and $190 \mathrm{ml}$. After electrophoresis according to the method of Laemmli (1970), the gels were dried and fluorographs prepared.

filtration on a column of Sephacryl S-200 (Text-fig. 4b). Most of the radioactivity eluted fairly late and at a position just after that of the molecular weight marker, chymotrypsinogen (mol. wt 25700 ). The molecular weight of the protein estimated by gel filtration was $21000 \pm 3000$. If whole blastocyst medium (Day 14) was analysed in a similar manner the elution pattern, as expected, was more complex. A large peak of radioactivity in the region of the void volume was particularly prominent. This consisted largely of the peak 1 material seen during ion-exchange chromatography.

After successive ion-exchange and gel chromatography, the low molecular weight acidic component was dialysed extensively against dilute buffer $(0.01 \mathrm{M}-\mathrm{Tris}-\mathrm{HCl} ; \mathrm{pH} 8.2)$ and freeze-dried. A portion was then subjected to two-dimensional PAGE and the resulting gel first stained with Coomassie blue (Pl. 3, Fig. 8) and then subjected to fluorography (Pl. 3, Fig. 9). It is clear from these results that the two-step chromatography procedure removed all detectable radioactive contaminants from the low molecular weight polypeptides. In addition, only a trace of other Coomassie blue positive material was detectable on the gel. These preliminary experiments indicate that $50-100 \mu \mathrm{g}$ of the protein, estimated by the method of Lowry et al. (1951), can be purified from the medium in which a single Day-14 conceptus is cultured for $24 \mathrm{~h}$.

\section{Trophoblast origin of the low molecular weight polypeptides}

To determine what tissue type produced the low molecular weight acidic protein, the inner cell mass and yolk sac were dissected from the trophoblast of a Day-14 blastocyst as completely 


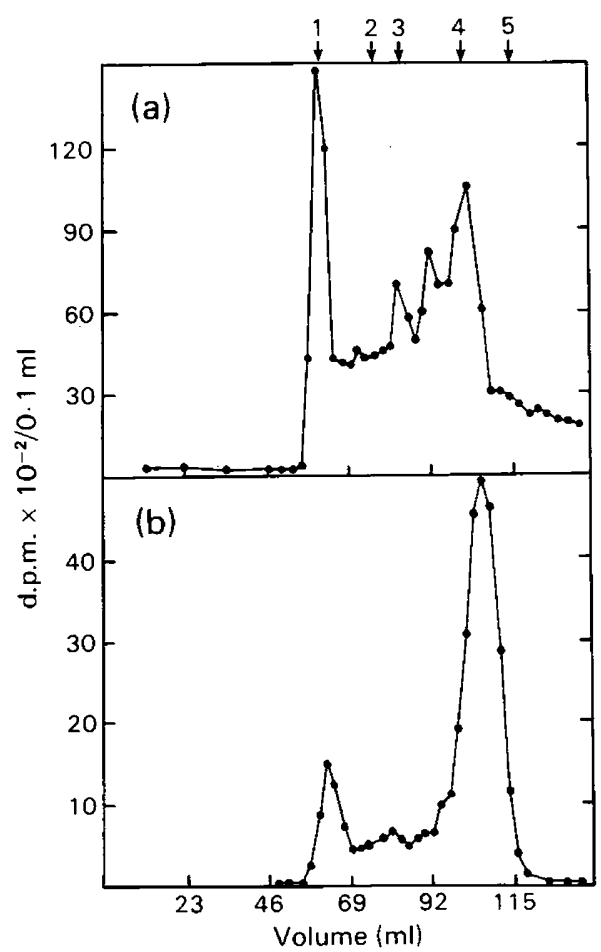

Text-fig. 4. Sephacryl S-200 gel chromatography of dialysed, unfractionated medium after incubation of a Day-14 conceptus (a) and of the 160-190 ml peak from the DEAE-cellulose salt gradient (b). The column $(90 \times 1.5 \mathrm{~cm})$ was eluted with $0.01 \mathrm{M}-$ Tris- $\mathrm{HCl}(\mathrm{pH} 8.2)$ containing $0.3 \mathrm{M}-\mathrm{NaCl}$ and $2.3 \mathrm{ml}$ fractions were collected. Elution positions of the standards, 1 (blue dextran), 2 (bovine serum albumin), 3 (ovalbumin), 4 (chymotrypsinogen), and 5 (ribonuclease), are shown by numbered arrows.

as possible. The yolk sac and pieces of trophoblast, free of inner cell mass, were then incubated separately with $\mathrm{L}-\left[{ }^{3} \mathrm{H}\right]$ leucine in the usual manner. Although the yolk sac produced and secreted a wide array of radioactive proteins (Pl. 3, Fig. 10), these were distinct from those secreted by the trophoblast (Pl. 3, Fig. 11). The low molecular weight acidic polypeptides therefore appeared to be of trophoblast rather than yolk sac origin.

\section{Discussion}

At Days 12-13 of pregnancy, the ovine blastocyst undergoes rapid elongation. This coincides with the time at which maternal recognition of pregnancy occurs (Moor \& Rowson, 1966a, b). We have demonstrated that during this critical period the conceptus releases only one major protein (Protein X) when it is cultured in vitro. By Day 14, however, the pattern of proteins synthesized and released by the blastocyst becomes more complex. This pattern of synthesis continues until Day 21, with the predominant components being Protein $\mathrm{X}$ and another protein of very high molecular weight and consisting of about $50 \%$ carbohydrate by weight (R. A. Masters, J. D. Godkin \& R. M. Roberts, unpublished results). By Day 23 the pattern of protein synthesis and release had changed markedly and Protein $X$ could no longer be distinguished. At Day 30, cultured chorioallantois releases very little radioactive protein into the medium and no Protein X. It is therefore tempting to suggest that because Protein X as well as some of the other components identified in the culture medium are produced transiently between Days 13 and 21 
of pregnancy that one or several of these might have some role in pregnancy recognition in the sheep.

An important finding in our experiments is that although Protein $\mathrm{X}$ is one of two major proteins recovered from the culture medium of conceptus incubations it is barely detectable in the tissues themselves. This observation has two implications. First, since it is released selectively from the tissue, Protein $\mathrm{X}$ is probably a secretory protein that is released by the unattached blastocyst when in utero. Second, it would be necessary to extract large amounts of conceptus tissue in order to obtain even a small quantity of Protein X.

Martal et al. (1979) reported the presence of a proteinaceous component (named trophoblastin) in Day-14-16 but not in Day-21-23 sheep conceptuses which was antiluteolytic when injected into uteri of cyclic sheep. It is clear that the appearance and disappearance of the putative antiluteolytic protein, trophoblastin, correlates with Protein $\mathrm{X}$ production by the trophoblast. In addition, we have demonstrated by immunocytochemical techniques that Protein $\mathrm{X}$ becomes associated with the uterine endometrium in the intact, pregnant uterus (J. D. Godkin, F. W. Bazer \& R. M. Roberts, unpublished results). Thus, it is possible that Protein $\mathrm{X}$ corresponds to trophoblastin.

Protein X has a molecular weight of about 21000 as measured by gel filtration and about 17000 by polyacrylamide gel electrophoresis in presence of SDS. The values are only slightly less than those reported by a number of workers (Chan, Robertson \& Friesen, 1976; Martal \& Djiane, 1977) for ovine placental lactogen which has been detected by radioreceptor assay in the Day-16 sheep conceptus (Martal \& Djiane, 1977). However, whereas ovine placental lactogen is a hormone that is synthesized in increasing amounts throughout pregnancy, the production of Protein $\mathrm{X}$ appears to be limited to only a short period in early pregnancy. Like ovine placental lactogen, Protein $\mathrm{X}$ consists of several isoelectric species which might have arisen by variable degrees of post-transitional modification of a single protein or the expression of more than one closely related gene. On the other hand ovine placental lactogen has been reported to be a neutral or slightly basic protein (pI 8.8: Chan et al., 1976; pI 7.2: Martal \& Djiane, 1977) which binds to DEAE-cellulose very weakly, if at all. By contrast, Protein $\mathrm{X}$ is acidic with a $\mathrm{pI}$ close to 5.5 when denatured in presence of urea. The fact that the native protein elutes very late in a salt gradient from DEAE-cellulose (at about $0.25 \mathrm{M}-\mathrm{NaCl}$ ) suggests that the $\mathrm{pI}$ of the native protein may be considerably lower than this value, and therefore very unlike that of ovine placental lactogen.

At present the functions of all of the proteins identified in the culture medium of sheep blastocysts remain unknown. However, the ability to generate significant amounts of the high molecular weight species as well as Protein X should permit testing of their roles without the complications of other protein contaminants being present.

The Research was supported by grant HD10436 from the National Institutes of Health. We thank Catherine Willis and Skip Bartol for surgical assistance. Florida Agricultural Experiment Station Paper Number 3010.

\section{References}

Barrett, L.A., McDowell, E.M., Frank, A.L., Harris, C.C. \& Trump, B.F. (1976) Long term organ culture of human bronchial epithelium. Cancer Res. 36, 1003-1010.

Basha, S.M.M., Bazer, F.W. \& Roberts, R.M. (1979) The secretion of a uterine specific, purple phosphatase by cultured explants of porcine endometrium dependency upon the state of pregnancy of the donor animal. Biol. Reprod. 20, 431441.

Basha, S.M.M., Bazer, F.W. \& Roberts, R.M. (1980) Effect of the conceptus on quantitative and qualitative aspects of uterine secretions in pigs. $J$. Reprod. Fert. 60, 41-48.

Chamberlain, J.P. (1979) Fluorographic detection of radioactivity in polyacrylamide gels with the watersoluble fluor, sodium salicylate. Analyt. Biochem. 98, 132-135.

Chan, J.S., Robertson, H.A. \& Friesen, H.G. (1976) The purification and characterization of ovine placental lactogen. Endocrinology 98, 65-76.

Fishel, S.B. \& Surani, M.A.H. (1980) Evidence for the synthesis and release of a glycoprotein by mouse blastocysts. J. Reprod. Fert. 59, 181-185. 
Horst, M.N. \& Roberts, R.M. (1979) Analysis of polypeptide turnover rates in Chinese Hamster ovary cells plasma membranes using two-dimensional electrophoresis. J. biol. Chem. 254, 5000-5007.

Laemmli, U.K. (1970) Cleavage of structural proteins during the assembly of the head of bacteriophage T4. Nature, Lond. 227, 680-685.

Laskey, R.A. \& Mills, A.D. (1975) Quantitative film detection of ${ }^{3} \mathrm{H}$ and ${ }^{14} \mathrm{C}$ in polyacrylamide gels by fluorography. Eur. J. Biochem. 252, 6510-6515.

Lowry, O.H., Rosebrough, N.J., Farr, A.L. \& Randall, R.J. (1951) Protein measurement with the folin phenol reagent. J. biol. Chem. 193, 265-275.

Martal, J. \& Djiane, J. (1977) The production of chorionic somatomammotrophin in sheep. J. Reprod. Fert. 49, 285-289.

Martal, J., Lacroix, M.C., Loudes, C., Saunier, M. \& Wintenberger-Torrès, S. (1979) Trophoblastin, an antiluteolytic protein present in early pregnant sheep. J. Reprod. Fert. 56, 63-73.

Moor, R.M. \& Rowson, L.E.A. (1964) Influence of the embryo and uterus on luteal function in the sheep. Nature, Lond. 201, 522-523.

Moor, R.M. \& Rowson, L.E.A. (1966a) The corpus luteum of the sheep: effect of the removal of embryos on luteal function. J. Endocr. 34, 497-502.

Moor, R.M. \& Rowson, L.E.A. (1966b) The corpus luteum of sheep: functional relationship between the embryo and the corpus luteum. J. Endocr. 34, 233-239.

Morton, H., Hegh, V. \& Clunie, G.J.A. (1974) Immunosuppression detected in pregnant mice by rosette inhibition test. Nature, Lond. 249, 459-460.

Morton, H., Hegh, V. \& Clunie, G.J.A. (1976) Studies of the rosette inhibition test in pregnant mice; evidence of immunosuppression? Proc. R. Soc. Lond. B 193, 413-419.

Morton, H., Rolfe, B., Clunie, G.J.A., Anderson, M.J. \& Morrison, J. (1977) An early pregnancy factor detected in human serum by the rosette inhibition test. Lancet i, 394-397.

Morton, H., Nancarrow, C.D., Scaramuzzi, R.J., Evison, B.M. \& Clunie, G.J.A. (1979) Detection of early pregnancy in sheep by the rosette inhibition test. $J$. Reprod. Fert. 56, 75-80.

O'Farrell, P.H. (1975) High resolution two dimensional electrophoresis of protein. J. biol. Chem. 250, $4007-4021$.

Rowson, L.E.A. \& Moor, R.M. (1967) The influence of embryonic tissue homogenate infused into the uterus on the life span of the corpus luteum in sheep. $J$. Reprod. Fert. 13, 511-516.

Trump, B.F., Resau, J. \& Barrett, L.A. (1980) Methods of organ culture for human bronchus. In Methods in Cell Biology, Vol. 21A, Normal Human Tissue and Cell Culture, pp. 1-14. Ed. D. M. Prescott. Academic Press, New York.

Received 24 June 1981 